\title{
Lithosphere Thickness and Diamond Content of Kimberlites
}

\author{
Chris Hatton \\ MSA Geoservices, Johannesburg, South Africa
}

\begin{abstract}
Heat flow into the lithosphere varies as a function of the thickness of the lithosphere. This can be seen from electromagnetic determinations of lithosphere thickness, where crustal heat flow increases as the lithosphere thins (Jones and Craven, 1999). Crustal heat flow is a combination of the heat generated in the crust and heat flowing into the lithosphere. The proportions vary widely, but on average, crustal radioactivity generates $40 \%$ of crustal heat flow (Pollack and Chapman, 1977).
\end{abstract}

A direct measurement of heat flow into the lithosphere can be obtained from the geothermal gradient in the lithosphere. This can be obtained from lithospheric xenoliths, using techniques developed by Boyd (1973) and subsequently refined (Brey and Kohler, 1990). Combining results obtained from both techniques yields the relation

$\mathrm{G}_{\mathrm{L}}=42.9-6.88 \ln \left(\mathrm{z}_{\mathrm{L}}\right)$

where

$\mathrm{G}_{\mathrm{L}}$ is the geothermal gradient in the lithosphere, and $\mathrm{z}_{\mathrm{L}}$ is the thickness of the lithosphere.

The reason for the increase in heat flow into the lithosphere as it thins is that this thinning is necessarily accompanied by a thickening of the underlying asthenosphere. The heat flow into $100 \mathrm{~km}$ lithosphere is twice that into $225 \mathrm{~km}$ thick lithosphere. Heat flow from the convecting asthenosphere is proportional to its thickness, raised to the power 4/3 (Davies, 1979). In the standard model of two-layer mantle convection, the base of the shallow convecting layer is at $660 \mathrm{~km}$. For this model the asthenosphere below $100 \mathrm{~km}$ thick lithosphere would be $560 \mathrm{~km}$ compared to $435 \mathrm{~km}$ below $225 \mathrm{~km}$ thick lithosphere, and heat flow into 100 $\mathrm{km}$ thick lithosphere would be only $40 \%$ higher than into $225 \mathrm{~km}$ thick lithosphere. Placing the base of the shallow convecting layer at $410 \mathrm{~km}$ means that the asthenosphere below $100 \mathrm{~km}$ lithosphere is $310 \mathrm{~km}$ compared to $185 \mathrm{~km}$ below $225 \mathrm{~km}$ thick lithosphere. The heat flow into $100 \mathrm{~km}$ lithosphere is then twice that into $225 \mathrm{~km}$ thick lithosphere, exactly as expected from observations. The conclusion that the base of the shallow convecting layer is at $410 \mathrm{~km}$ supports a model of multilayered mantle convection, rather than twolayer mantle convection (Hatton, 2008).

The thickness of the lithosphere determines whether diamond is stable. The critical lithosphere thickness is determined by the intersection of the diamond-graphite curve (Kennedy and Kennedy, 1976) with the adiabatic gradient at the base of the lithosphere (McKenzie and
Bickle, 1988) and is $168 \mathrm{~km}$. A determination of lithosphere thickness is therefore a first indication of the economic viability of a kimberlite prospect.

Xenoliths with coexisting garnet, clinopyroxene and orthopyroxene allow an accurate estimate of the geothermal gradient from the parameterisations of Brey and Kohler (1990). Xenoliths are not normally accessible in the early stages of kimberlite evaluation so methods relying on single mineral grains must be employed. The nickel content of garnet is temperature dependent, but analysis for the trace element concentrations that are present in garnet must be carried out with laser ablation-inductively coupled mass spectrometry, a relatively expensive technique. Manganese in garnet is also temperature sensititive and has the advantage that it is readily detectable in routine electron microprobe analysis. With a moderate increase in counting times and appropriate choice of detector crystals, the manganese thermometer of Grutter et al. (1999) can be used to obtain results comparable to those obtained from nickel in garnet thermometry. In combination with a modification of the barometer of Grutter et al. (2006), geotherms obtained from single garnet grains consistently separate kimberlites with economic concentrations of diamonds from kimberlites that are effectively barren.

The geothermal profiles are remarkably effective in indicating diamond potential, given the complex history that kimberlites have experienced. Many kimberlites contain a population of diamonds that originate below the lithosphere, and the thermal state of the lithosphere is perturbed during the kimberlite event.

The kimberlite magma forms at the base of the lithosphere (Tainton and McKenzie, 1994) and the fact that many kimberlites and lamproites contain a proportion of ultradeep diamonds demonstrates that kimberlite magmatism is preceded by the ascent of diapirs from the transition zone and lower mantle. These diapirs are stalled at the base of the lithosphere where they cool and preserve the ultradeep diamonds. This stalling is important for the economic concentration of diamonds, since lamproites and other rocks that have not stalled below thick lithosphere do not contain economic proportions of diamonds.

The kinked geotherm of Boyd (1973) is an illustration of perturbation of the lithospheric geotherm by a rising diapir. The rising diapir increases the geothermal 
gradient as it rises into the lithosphere. Kimberlite is generated from a melt fraction segregating from the diapir. As the diapir ascends kimberlites are generated from progressively shallower depths. This accounts for the observation that in a single pipe the early phases of kimberlite are diamondiferous, while later kimberlites are poorly diamondiferous or barren.

The Finsch geotherm is in a sense the opposite of Boyd's kinked geotherm; at Finsch the geothermal gradient decreases toward the base of the lithosphere. This is an example of the process of subcretion, where a rising diapir accretes to the base of the lithosphere, thickening and cooling the lithosphere. At Finsch the subcreted diapir is part of the kimberlite event, and subcretion is on a small scale, but on a larger scale subcretion of diapirs is the main mechanism of lithosphere growth (Aulbach et al., 2007).

\section{References}

Aulbach, S., Griffin, W., Pearson, N., O'Reilly, S., Doyle, B., 2007. Lithosphere formation in the central Slave Craton (Canada): plume subcretion or lithosphere accretion? Contributions to Mineralogy and Petrology, 154, 409-427.

Boyd, F. R., 1973, A pyroxene geotherm. Geochimica et Cosmochimica Acta, 37, 2533-2546.

Brey, G. P., Kohler, T., 1990. Geothermobarometry in fourphase lherzolites II. New thermobarometers, and practical assessment of existing thermobarometers. Journal of Petrology, 31, 1353-378.

Davies, G. F., 1979. Thickness and thermal history of continental crust and root zones. Earth and Planetary Science Letters, 44, 231-238.

Grütter, H., Latti, D., Menzies, A., 2006. Cr-saturation arrays in concentrate garnet compositions from kimberlite and their use in mantle barometry. Journal of Petrology, 47, 801-820.

Grütter, H. S., Apter, D. B., Kong, J., 1999. Crust-mantle coupling: evidence from mantle-derived xenocrystic garnets. In Proc. VIIth International Kimberlite Conference, eds J.J. Gurney, J.L. Gurney, M.D. Pascoe and S.H. Richardson, pp. 307-313. Red Roof Design, Cape Town.

Hatton, C., 2008. Foundered lower continental crust in the source of group 2 kimberlites. Extended abstract, 9IKC-A-00355.

Jones, A. G., Craven, J. A., 1999. Area selection for diamond exploration using deep-probing electromagnetic surveying. Lithos, 77, 765-782.

Kennedy, C. S., Kennedy, G. G., 1976. The equilibrium boundary between graphite and diamond. Journal of Geophysical Research, 81, 2467-2470.

McKenzie, D., Bickle, M. J., 1988. The volume and composition of melt generated by extension of the lithosphere. Journal of Petrology, 29, 625-679.

Pollack, H. N., Chapman, D. S., 1977. On the regional variation of heat flow, geotherms and lithospheric thickness. Tectonophysics, 38, 279-296.

Tainton, K. M., McKenzie, D., 1994. The generation of kimberlites, lamproites, and their source rocks. Journal of Petrology, 35, 787-817. 